\title{
PENGARUH PEMBERIAN SUBKRONIK EKSTRAK KELOPAK BUNGA ROSELLA (Hibiscus Sabdariffa L.) TERHADAP KADAR SGPT SGOT DAN ALP
}

\author{
Nurkhasanah', Moch. Saiful Bachri' ${ }^{1}$, Nofa Risma Azis ${ }^{2 *}$ \\ ${ }^{1}$ Fakultas Farmasi, Universitas Ahmad Dahlan, Yogyakarta, Indonesia \\ ${ }^{2}$ Program Pascasarjana Farmasi, Universitas Ahmad Dahlan, Yogyakarta, Indonesia
}

Received May 23, 2016; Accepted August 15, 2016

\begin{abstract}
Roselle (Hibiscus sabdariffa L.) has been known as traditional medicinal plants. It needed to evaluate the safety of roselle extract on long-term oral administration. The research aimed to determine the savety of ethanolic extract of roselle calyx. Subchronic toxicity study of ethanolic extract of roselle calyx had been carried out on 60 Sprague Dawleys (SD) rats for 28 days. The roselle extract was administered orally every day, with doses of 50,100 and $200 \mathrm{mg} / \mathrm{kgBW}$. There are 2 satellite groups, kept for another 14 days after the treatment in order to detect a delayed occurrence of toxic effect. Satellite group was given extract $200 \mathrm{mg} / \mathrm{kgBW}$ for 28 days and followed aquadest treatment for 14 days. At the end of experiment the blood was collected for meansuring SGPT, SGOT and ALP activity. The result showed that treatment of roselle calyx extract had no significant changes in SGPT SGOT, ALP activity. The delayed effect was not also observed. The ethanolic extract of roselle calyx didn't show toxic effects on the liver on subchronic administration.
\end{abstract}

Key words: Roselle (Hibiscus sabdariffa, L.), SGPT, SGOT, ALP

\section{PENDAHULUAN}

Rosella (Hibiscus sabdariffa L.) tanaman yang cukup banyak dimanfaatkan oleh masyarakat Indonesia. Secara empiric dan praklinik rosella memiliki aktivitas yang cukup banyak seperti antipiretika, antibakterial, antioksidan, antihipertensi, antikolesterol (Reanmongkol dan Itharat, 2007; Ajay et al., 2007). Rosella mengandung flavonoid gossypetin, hibiscetine, sabdarerine, ascorbic acid, mucilage, calcium citrate (Ali et al., 2005).

Beberapa penelitian menunjukkan aktivitas farmakologi dari rosella, beberapa diantaranya adalah rosella dapat menurunkan tekanan darah pada tikus (Odigie et al., 2003) dan telah diuji secara klinis pada pasien essential hypertension (Herrera et al., 2004). Ekstrak rosella ditemukan dapat mencegah stres oksidatif eritosit manusia dari lipid peroksidase (Suboh et al., 2004). Ekstrak rosella juga dapat menurunkan kadar lipid dan menunjukkan aktivitas sebagai antiaterosklerotis pada kelinci yang diinduksi kolesterol tinggi (Chen et al., 2003). Seduhan dari rosella mengandung polifenol yang berfungsi sebagai antioksidan dan antiinflamasi (Kao et al., 2009). Ekstrak rosella juga menunjukkan aktivitas hepatoprotektif pada tikus yang diinduksi DMBA dengan menurunkan aktivitas SGPT, SGOT dan ALP (Nurkhasanah dan Rahardhian., 2015)

Secara empirik banyak tanaman obat digunakan untuk menanggulangi penyakit degeneratif yang membutuhkan pengobatan dalam jangka waktu yang lama. Demikian juga banyak produk jadi obat tradisional yang bahan bakunya adalah rosella yang beredar di masyarakat dengan indikasi sebagai antioksidan. Berkembangnya penggunaan rosella di masyarakat sehingga perlu dilakukan uji mengenai keamanan penggunaan rosella tersebut. Sehingga untuk memperoleh data mengenai keamanan pemakaian jangka panjang rosella, perlu dilakukan penelitian toksisitas subkronis ekstrak kelopak bunga rosella pada hewan percobaan.

Pada uji toksistas akut, tidak ditemukan toksistas pada pemberian $5000 \mathrm{mg} / \mathrm{kgBB}$ ekstrak etanol rosella secara oral pada tikus (Sari, 2016). 
Hepar mempunyai peranan pada setiap fungsi metabolik tubuh. Pada proses metabolisme, sejumlah senyawa xenobiotik berpotensi untuk menimbulkan kerusakan pada hepar (hepatotoksik). Radikal bebas yang dihasilkan dari proses metabolisme suatu xenobiotik dapat menginduksi lesi dari hepar dan bereaksi dengan penyusun seluler hepar, seperti protein, lipid, RNA dan DNA. Kerusakan pada hepar akan ditunjukkan oleh aktivitas enzim seluler yang semakin meningkat.

Enzim hati yang dapat dijadikan pertanda kerusakan hati antara lain aminotransferase (transaminase) dan Alkalin fosfatase (ALP). Golongan enzim aminotransferase adalah serum alanin amino transferase (Serum Glutamic Pyruvic Transaminase atau SGPT) dan serum aspartat amin transferase (Serum Glutamic Oxaloacetic Transaminase atau SGOT). Enzim-enzim tersebut merupakan indikator yang spesifik untuk menentukan kerusakan sel hati. Alkalin fosfatase (ALP) merupakan kelompok enzim yang bekerja menghidrolisis ester fospat pada suasana alkali. Kadar ALP tertinggi di dalam tubuh terdapat pada sel-sel yang mengalami pembelahan dengan cepat seperti epitel usus, jaringan sel tubulus proksimal ginjal dan plasenta. Peningkatan kadar enzimenzim ini mencerminkan adanya kerusakan sel hepar.

Berdasarkan uraian diatas serta didukung penelitian yang sebelumnya maka penelitian ini dilakukan untuk mengetahui keamanan pemberian ekstrak kelopak bunga rosella pada hepar tikus, dengan mengukur aktivitas SGOT, SGPT dam ALP.

\section{METODE PENELITIAN \\ Bahan dan Alat}

Bahan yang digunakan adalah kelopak bunga rosella yang diperoleh dari petani rosella Kediri, Jawa Timur yang dipanen pagi hari sebelum matahari terbit, etanol $70 \%$ (Merck), hewan uji tikus betina Sprague Dawley berumur 6-8 minggu dengan berat badan 120-180 gram, berasal dari Laboratorium Penelitian dan Pengujian Terpadu (LPPT) UGM, Yogyakarta, reagen kit SGOT, SGPT dan ALP (Dyasis $\left.{ }^{\circledR}\right)$.

Alat-alat gelas (Pyrex), seperangkat alat bedah, alat suntik, jarum oral, mikropipet (Socorex), yellow tip, blue tip, (Assistent), corong Buchner, vakum (Gast), rotary evaporator (Heidolph), stirrer (Ika Labortechnik), waterbath (Memmert), timbangan analitik (Ohaus), toples, oven (Binder), Spektrofotometer (Shimadzu).

\section{Ekstraksi}

Ekstraksi dengan menggunakan metode maserasi. Pelarut yang digunakan dalam ekstraksi ini adalah etanol $70 \%$. Seribu lima ratus gram serbuk kelopak bunga rosella diekstraksi dengan pelarut etanol $70 \% 6000 \mathrm{~mL}$ (1:4) menggunakan metode maserasi dengan pengadukan selama kurang dari 3 jam, kemudian didiamkan sampai 24 jam. Ekstrak cair hasil penyarian dengan lalu dievaporasi dan kemudian dipanaskan di waterbath hingga diperoleh ekstrak kental.

\section{Standarisasi Ekstrak \\ Penetapan Kadar Flavonoid}

Penetapan kadar total flavonoid dilakukan dengan spektrofotometri menggunakan reagen aluminium klorida sesuai prosedur Chang et al., (2002). Menimbang $50 \mathrm{mg}$ kuersetin kemudian dilarutkan dengan etanol $50 \mathrm{ml}$ di encerkan hingga garis batas. Larutan tersebut sebagai larutan induk yang selanjutnya di encerkan dengan etanol sehingga diperoleh minimal 7 konsentrasi yang berbeda. Tiap konsentrasi di pipet sebanyak $2 \mathrm{~mL}$ larutan kemudian ditambahkan dengan $0,1 \mathrm{ml}$ alumunium klorida $\left(\mathrm{AlCl}_{3}\right) \quad 10 \%$ yang telah dilarutkan dengan etanol, $0,1 \mathrm{ml} \mathrm{Na}$ Asetat, 2,8 ml aquadest kemudian divortex, inkubasi campuran larutan pada suhu kamar selama 30 menit. Selanjutnya didiukur serapannya menggunakan spektofotometer UV-Vis pada $430 \mathrm{~nm}$ dengan menggunakan larutan blangko.

\section{Penetapan Kadar Fenolik Total}

Penetapan kadar polifenol pada sampel dibuat dengan menimbang sebanyak 50,0 mg ekstrak etanol kelopak merah bunga rosella dilarutkan sampai volume 50,0 ml dengan campuran etanol : aquades (1:1). Larutan ekstrak yang diperoleh dipipet $300 \mu \mathrm{l}$ dan ditambah 1,5 ml reagen FolinCiocalteau dan digojog. Setelah didiamkan selama 3 menit, ditambah 1,2 ml larutan $\mathrm{Na} 2 \mathrm{CO} 37,5 \%$ dan didiamkan lagi pada range operating time pada 
suhu kamar. Absorbansi larutan ekstrak diukur dengan spekrofotometer UV-Vis pada panjang gelombang absorbansi maksimum (Lim dan Murtijaya, 2007).

\section{Perlakuan Hewan Uji}

Hewan uji telah mendapat persetujuan etik dari komite etik penelitian Universitas Ahmad Dahlan Yogyakarta dengan nomor 011505043. Pengujian toksisitas rosella sesuai dengan Peraturan Kepala BPOM RI Nomor 7 Tahun 2014 tentang Pedoman Uji Toksisitas Non klinik secara In Vivo. Hewan uji dibagi menjadi enam kelompok, masing-masing terdiri dari 10 tikus SD. Sebelumnya hewan uji diaklimatisasi selama 7 hari. Pengelompokan hewan uji sebagai berikut:

Kelompok I : Kontrol pelarut, tikus diberi larutan pembawa (aquadest) secara peroral.

Kelompok II : Hewan uji diberi ekstrak dengan dosis $50 \mathrm{mg} / \mathrm{kgBB}$ secara peroral selama 28 hari.

Kelompok III : Hewan uji diberi ekstrak dengan dosis $100 \mathrm{mg} / \mathrm{kgBB}$ secara peroral selama 28 hari.

Kelompok IV : Hewan uji diberi ekstrak dengan dosis $200 \mathrm{mg} / \mathrm{kgBB}$ secara peroral selama 28 hari.

Kelompok V dan VI merupakan kelompok satelit, untuk melihat ketoksikan yang presisten atau reversible

Kelompok V : Kontrol satelit pelarut, hewan uji diberi larutan pembawa (aquadest) secara peroral selama 42 hari.

Kelompok VI : Hewan uji diberi ekstrak dengan dosis $200 \mathrm{mg} / \mathrm{kgBB}$ secara peroral selama 28 hari, dan selanjutnya selama 14 hari diberi aquadest.

Setelah diaklimatisasi selama 7 hari dan 28 hari perlakuan kelompok I, II, III, dan IV diambil darahnya dan kemudian dilakukan penetapan kadar SGPT, SGOT dan ALP. Sedangkan pada kelompok $\mathrm{V}$ dan IV dilanjutkan hingga hari ke-43 dan dilakukan pengambilan darah untuk diakukan penetapan kadar SGPT, SGOT dan ALP.

\section{Penetapan Kadar SGPT}

Penetapan aktivitas SGPT ditetapkan berdasarkan reaksi enzimatik menggunakan reagen kit Dyasis ${ }^{\circledR}$ SGPT (R1) TRIS pH 7,15 sebanyak $140 \mathrm{mmol} / \mathrm{L}$, L-alanine $700 \mathrm{mmol} / \mathrm{L}$ dan $\mathrm{LDH}$ (lactate dehydrogenase) $\geq 2300 \mathrm{U} / \mathrm{L}$ : reagen SGPT (R2) 2- oksoglutarate $85 \mathrm{mmol} / \mathrm{L}$ dan $\mathrm{NADH}$ 1mmol /L. Larutan sampel berisi campuran R1 dan R2 dengan perbandingan $4: 1$. Sebanyak $600 \mu 1$ reagen kit SGPT direaksikan dengan $60 \mu \mathrm{l}$ sampel, divortex dan diinkubasi pada suhu kamar selama 1 menit selanjutnya sampel dibaca absorbansinya menggunakan spektrofoto-meter pada panjang gelombang $340 \mathrm{~nm}$. Prosedur penetapan SGPT berdasarkan prosedur kerja dari Dyasis ${ }^{\circledR}$.

\section{Penetapan kadar SGOT}

Penetapan aktivitas SGOT ditetepkan berdasarkan reaksi enzimatik menggunakan reagen kit Dyasis ${ }^{\circledR}$ SGOT (R1) TRIS pH 7,65 sebanyak $110 \mathrm{mmol} / \mathrm{L}$, L-aspartate $320 \mathrm{mmol} / \mathrm{L}, \mathrm{MDH}$ (malate dehydrogenase) $\geq 800 \mathrm{U} / \mathrm{L}$ dan $\mathrm{LDH}$ (lactate dehydrogenase) $\geq 1200 \mathrm{U} / \mathrm{L}$ : reagen SGOT (R2) 2-oksoglutarate $65 \mathrm{mmol} / \mathrm{L}$ dan $\mathrm{NADH} 1$ mmol/L. Larutan sampel berisi campuran R1 dan R2 dengan perbandingan 4:1. Sebanyak $600 \mu 1$ reagen kit SGOT direaksikan dengan $60 \mu \mathrm{l}$ sampel, divortex dan diinkubasi pada suhu kamar selama 1 menit selanjutnya sampel dibaca absorbansinya menggunakan spektrofotometer pada panjang gelombang $340 \mathrm{mn}$. Prosedur penetapan SGOT berdasarkan prosedur kerja dari Dyasis ${ }^{\circledR}$.

\section{Penetapan kadar ALP}

Penetapan aktivitas ALP ditetapkan berdasarka reaksi enzimatik menggunakan reagen kit Dyasis ${ }^{\circledR}$ ALP yang terdiri dari (reagen 1) diethanolamine $\mathrm{pH}$ 9,8 sebanyak $1,2 \mathrm{mmol} / \mathrm{L}$ dan magnesium chloride $0,6 \mathrm{mmol} / \mathrm{L}$; (reagen 2) $\mathrm{p}$ nitrophenylphosphate $50 \mathrm{mmol} / \mathrm{L}$. Larutan sampel berisi campuran reagen 1 dan reagen 2 dengan perbandinga 4:1. Sebanyak $600 \mu 1$ reagen kit ALP direaksikan dengan $12 \mu \mathrm{l}$ sampel, divortex dan diinkubasi pada suhu kamar selama 1 menit selanjutnya sampel dibaca absorbansinya menggunakan spektrofoto-meter pada panjang gelombang $405 \mathrm{~nm}$, prosedur penetapan aktivitas ALP berdasarkan prosedur kerja dari Dyasis ${ }^{\circledR}$.

\section{HASIL DAN PEMBAHASAN}

Penelitian ini bertujuan untuk mengetahui pengaruh pemberian subkronis ekstrak kelopak bunga rosella yang diberikan secara peoral pada pemakaian jangka panjang dengan berbagai tingkat 
dosis terhadap kadar SGPT, SGOT dan ALP pada hewan uji.

\section{Standarisasi Ekstrak \\ Analisis Kadar Fenolik}

Kadar fenolik total dari ekstrak etanol kelopak bunga rosella ditetapkan dengan menggunakan peraksi Folin-Ciocalteau. Prinsip reaksi fenolik ini adalah adanya reaksi reduksi dari gugus fenolik terhadap asam heteropoli (fosfomolibdatfosfotungstat) yang terdapat dalam peraksi FolinCiocalteau menjadi suatu kompleks molibdenumtungsten berwarna biru dengan struktur yang belum diketahui dan dapat diukur serapannya dengan spektrofotometer visibel. Suasana basa dapat diciptakan dengan penambahan $\mathrm{Na}_{2} \mathrm{CO}_{3} \quad 7,5 \%$ (natrium karbonat) sehingga terjadi disosiasi proton pada senyawa fenolik menjadi ion fenolat. Warna biru yang terbentuk akan semakin pekat, setara dengan konsentrasi ion fenolat yang terbentuk.

Hasil penetapan kandungan fenolik total diperoleh $\mathrm{y}=0,0199 \mathrm{x}+0,1496$ dan $\mathrm{r}=0,9948$, dimana $\mathrm{x}=$ konsentrasi $(\mu \mathrm{g} / \mathrm{mL})$ dan $\mathrm{y}=$ absorbansi. Kandungan fenolik total rata-rata ekstrak kelopak bunga rosella yang diperoleh kadar sebesar $1,96 \% \pm 0,04$.

\section{Analisis Kadar Flavonoid Total}

Kadar flafonoid total dari ekstrak kelopak bunga rosella ditetapkan dengan menggunakan pereaksi $\mathrm{AlCl}_{3}$. Aluminium klorida akan membentuk kompleks warna dengan flavonoid yang ditandai dengan terbentuknya warna kuning. Penambahan $\mathrm{Na}$ asetat dengan tujuan agar kompleks warna yang terbentuk stabil dan dapat dibaca serapannya.

Hasil penetapan kandungan flavonoid diperoleh $\mathrm{y}=0,0749 \mathrm{x}+0,0346$ dan $\mathrm{r}=0,9856$ dimana $\mathrm{x}=$ konsentrasi $(\mu \mathrm{g} / \mathrm{mL})$ dan $\mathrm{y}=$ absorbansi. Kandungan flavonoid total rata-rata ekstrak kelopak bunga rosella yang diperoleh kadar sebesar $0,52 \% \pm 0,02$.

\section{Penetapan Kadar SGPT, SGOT dan ALP}

Pengukuran aktivitas SGOT, SGPT dan ALP pada kelompok I, II, III dan IV dilakukan pada hari ke29 setelah pemberian ekstrak etanol kelopak bunga rosella selama 28 hari. Hasil pengukuran SGPT secara rinci dapat dilihat pada Tabel I serta disajikan pada Gambar 1.

Tabel I. Kadar SGPT, SGOT dan ALP setelah pemberian ekstrak kelopak bunga rosella.

\begin{tabular}{cccc}
\hline Kelompok & $\begin{array}{c}\text { Kadar SGOT }(\mathrm{U} / \mathrm{L}) \\
{[\text { rerata } \pm \mathrm{SD})}\end{array}$ & $\begin{array}{c}\text { Kadar SGPT }(\mathrm{U} / \mathrm{L}) \\
\text { [rerata } \pm \mathrm{SD})\end{array}$ & $\begin{array}{c}\text { Kadar ALP }(\mathrm{U} / \mathrm{L}) \\
\text { [rerata } \pm \text { SD) }\end{array}$ \\
\hline Kontrol & $69,45 \pm 2,25$ & $25,65 \pm 3,10$ & $108,63 \pm 14,12$ \\
Dosis $50 \mathrm{mg} / \mathrm{kgBB}$ & $70,85 \pm 4,50$ & $26,01 \pm 2,55$ & $109,72 \pm 9,210$ \\
Dosis $100 \mathrm{mg} / \mathrm{kgBB}$ & $71.02 \pm 3.64$ & $26,70 \pm 3,52$ & $117,17 \pm 5,72$ \\
Dosis $200 \mathrm{mg} / \mathrm{kgBB}$ & $70.15 \pm 3.89$ & $26,18 \pm 2,14$ & $110,83 \pm 7,78$ \\
Normal $^{\mathrm{a}}$ & $65-203$ & $16-48$ & $26-147$ \\
\hline
\end{tabular}

Keterangan : * berbada signifikan dengan kontrol

${ }^{\text {a }}$ Charles River Laboratory

Tabel II. Kadar SGOT, SGPT dan ALP pada kelompok satelit, setelah pemberian ekstrak kelopak bunga rosella selama 28 hari dan dilanjutkan 14 hari diberikan aquadest

\begin{tabular}{cccc}
\hline Kelompok & $\begin{array}{c}\text { Kadar SGOT (U/L) } \\
{[\text { rerata } \pm \text { SD) }}\end{array}$ & $\begin{array}{c}\text { Kadar SGPT (U/L) } \\
\text { [rerata } \pm \text { SD) }\end{array}$ & $\begin{array}{c}\text { Kadar ALP (U/L) } \\
\text { [rerata } \pm \text { SD) }\end{array}$ \\
\hline Satelit (kontrol) & $69,80 \pm 366$ & $25,83 \pm 4,26$ & $113,86 \pm 16,04$ \\
Satelit (Dosis $200 \mathrm{mg} / \mathrm{kgBB})$ & $67,01 \pm 3,99$ & $24,78 \pm 4,04$ & $106,70 \pm 17,05$ \\
Normal $^{\mathrm{a}}$ & $65-203$ & $16-48$ & $26-147$ \\
\hline
\end{tabular}

Keterangan : * berbada signifikan dengan kontrol

${ }^{\text {a }}$ Charles River Laboratory 


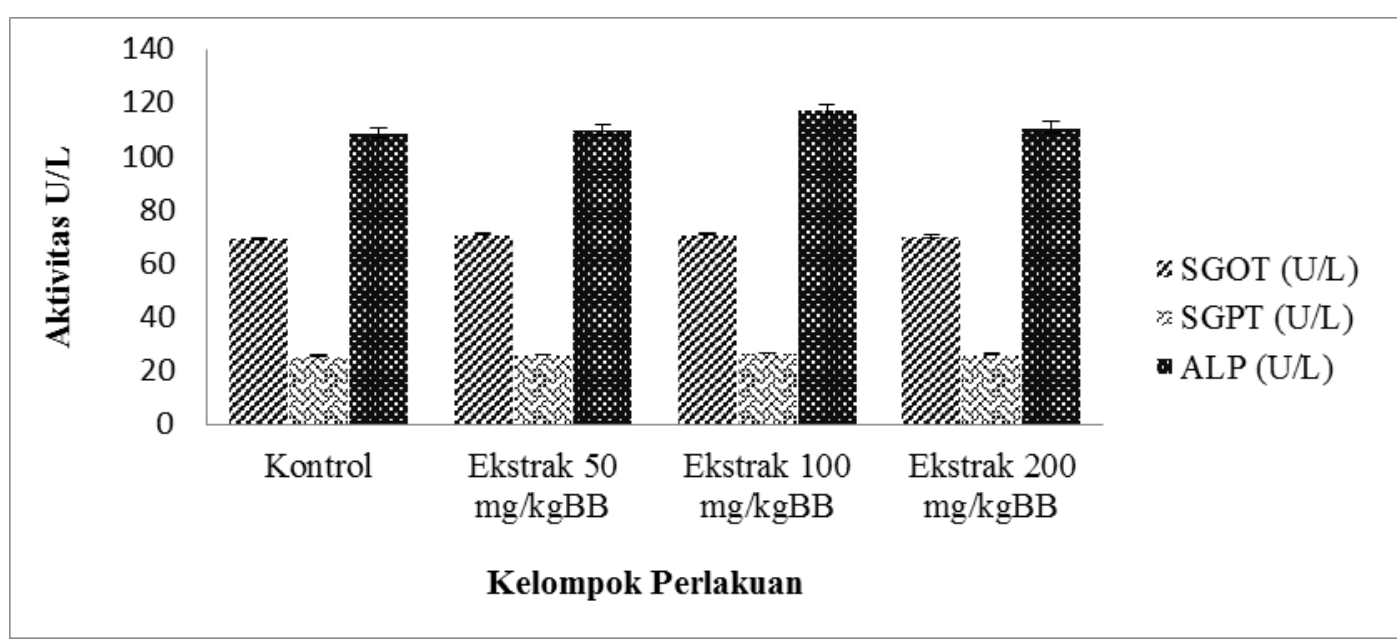

Gambar 1. Grafik kadar SGPT, SGOT dan ALP setelah pemberian ekstrak kelopak bunga rosella.

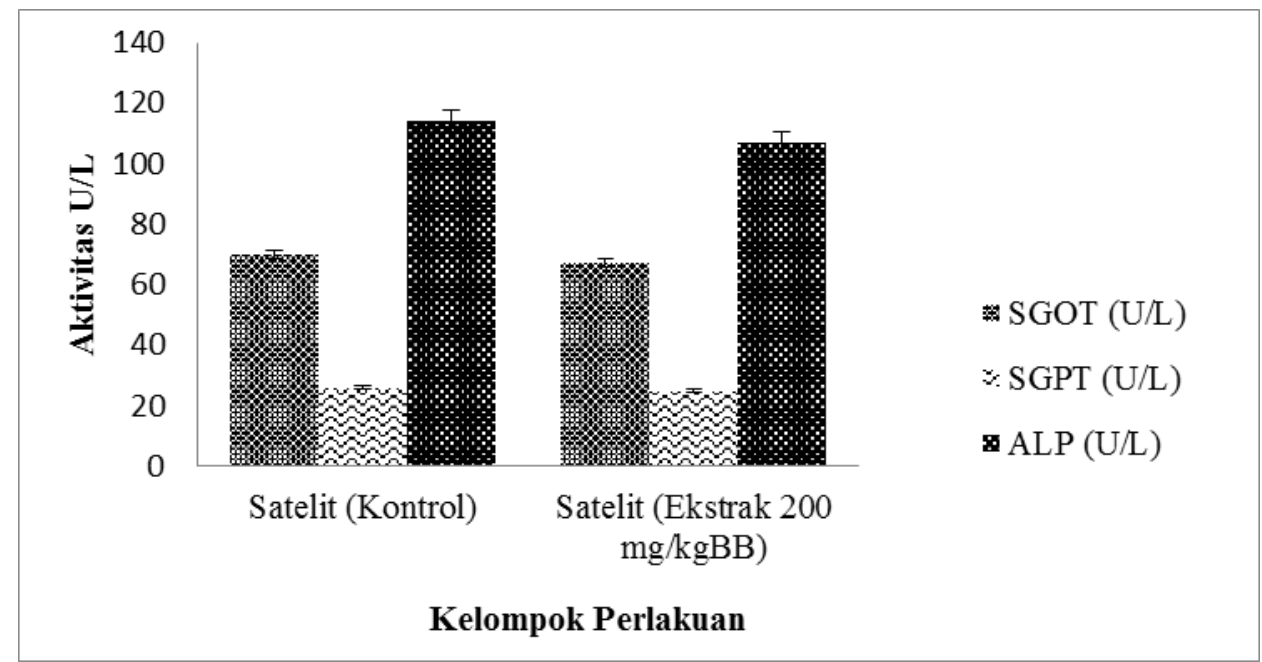

Gambar 2. Grafik kadar SGPT, SGOT dan ALP kelompok satelit

Hasil ANOVA pada kadar SGOT, SGPT dan ALP yang tidak menunjukkan adanya perbedaan kadar yang signifikan $(\mathrm{p}<0,05)$ antara kelompok tikus kontrol dengan kelompok perlakuan ekstrak kelopak bunga rosella dosis 50, 100 dan 200 $\mathrm{mg} / \mathrm{kgBB}$, sehingga dapat dikatakan semua hewan uji memiliki kondisi yang sama. Kadar ALP pada tikus yang diberikan ekstrak kelopak bunga rosella dengan variasi dosis 50, 100, dan $200 \mathrm{mg} / \mathrm{kgBB}$ terjadi kenaikan sebanding dengan dosis yang diberikan, tetapi kenaikkan kadar tersebut tidak signifikan. Aktivitas SGOT, SGPT dan ALP dibandingkan dengan kadar normal, terlihat bahwa kadar SGOT, SGPT dan ALP setiap kelompok berada pada rentang normal. Hasil penelitian toksikologi menunjukkan bahwa ada peningkatan aktivitas SGOT dan SGPT pada kelompok yang diberikan ekstrak metanol-air rosella selama 10 dan 15 hari. (Akindahunsi dan Olaleye, 2003). Penelitian toksisitas subkronik ekstrak air rosella dengan dosis 50 dan $200 \mathrm{mg} / \mathrm{kg}$ BB menunjukkan peningkatan SGOT dan SGPT yang signifikan (Sireeratawong et al., 2013)

Pengukuran aktivitas SGOT, SGPT dan ALP pada kelompok V dan VI dilakukan pada hari ke43 setelah pemberian ekstrak etanol kelopak bunga rosella selama 28 hari dan 14 hari selanjutnya diberikan aquadest secara peroral. Hasil 
pengukuran SGPT secara rinci dapat dilihat pada Tabel II serta disajikan pada Gambar 2.

Pada hari ke-43 dilakukan pengukuran kadar SGOT, SGPT dan ALP untuk kelompok satelit (kontrol dan dosis $200 \mathrm{mg} / \mathrm{kgBB}$ ). Pemberian ekstrak etanol kelopak bunga rosella selama 28 hari dan dilanjutkan pengamatan selama 14 hari tidak ada perbedaan yang signifikan dengan kelompok kontrol satelit. Hal ini menunjukkan bahwa tidak adanya efek toksik yang tertunda karena pemberian ekstrak kelopak bunga rosella. Rosella memiliki efek hepatoprotektor dan antioksidan pada tikus Wistar yang diinduksi $\mathrm{CCl}_{4}$ dan diberikan ekstrak metanol rosella dalam dosis 50 dan $100 \mathrm{mg} / \mathrm{kg}$ BB dapat meningkatkan enzim SGOT, SGPT serta ALP (Adetutu et al., 2013). Pemberian jangka panjang ekstrak etanol kelopak bunga rosella tidak menyebabkan perubahan pada kadar SGOT, SGPT dan ALP.

\section{KESIMPULAN}

Hasil pemberian subkronik ekstrak etanol kelopak bunga rosella dilihat dari kadar SGPT, SGOT dan ALP tidak menimbulkan toksisitas.

\section{UCAPAN TERIMA KASIH}

Penulis mengucapkan terima kasih kepada Ditjen DIKTI atas pembiayaan melalui Hibah Penelitian TIM Pascasarjana.

\section{DAFTAR PUSTAKA}

Adetutu, A. and Owoade, A.O., 2013. Hepatoprotective and Antioxidant Effect of Hibiscus Polyphenol Rich Extract (HPE) Against Carbon Tetrachloride (CCL4)Induced Damage in Rats. British Journal of Medicine and Medical Research, 3(4), 1574.

Ajay, M., Chai, H.J., Mustafa, A.M., Gilani, A.H. and Mustafa, M.R., 2007. Mechanisms of the anti-hypertensive effect of Hibiscus sabdariffa L. calyces. Journal of Ethnopharmacology, 109(3), 388-393.

Akindahunsi, A.A. and Olaleye, M.T., 2003. Toxicological investigation of aqueousmethanolic extract of the calyces of Hibiscus sabdariffa L. Journal of ethnopharmacology, 89(1), 161-164.

Ali, B.H., Wabel, N.A. and Blunden, G., 2005.Phytochemical,pharmacological and toxicological aspects of Hibiscus sabdariffa L.: a review. Phytotherapy research, 19(5), 369-375.

BPOM RI, 2014, Peraturan Kepala Badan Pengawas Obat dan Makanan Republik Indonesia Nomor 7 Tahun 2014 tentang Pedoman Uji Toksisitas Nonklinik secara In Vivo, BPOM RI, Jakarta.

Chang, C.C., Yang, M.H., Wen, H.M. and Chern, J.C., 2002. Estimation of total flavonoid content in propolis by two complementary colorimetric methods. Journal of food and drug analysis, 10(3).

Chen, C.C., Hsu, J.D., Wang, S.F., Chiang, H.C., Yang, M.Y., Kao, E.S., Ho, Y.C. and Wang, C.J., 2003. Hibiscus sabdariffa extract inhibits the development of atherosclerosis in cholesterol-fed rabbits. Journal of Agricultural and Food Chemistry, 51(18), 5472-5477.

Odigie, I.P., Ettarh, R.R. and Adigun, S.A., 2003. Chronic administration of aqueous extract of Hibiscus sabdariffa attenuates hypertension and reverses cardiac hypertrophy in $2 \mathrm{~K}-1 \mathrm{C}$ hypertensive rats. Journal of Ethnopharmacology, 86(2), 181-185.

Herrera-Arellano, A., Flores-Romero, S., ChavezSoto, M.A. and Tortoriello, J., 2004. Effectiveness and tolerability of a standardized extract from Hibiscus sabdariffa in patients with mild to moderate hypertension: a controlled and randomized clinical trial. Phytomedicine, 11(5), 375-382.

Kao, E.S., Hsu, J.D., Wang, C.J., Yang, S.H., Cheng, S.Y. and Lee, H.J., 2009. Polyphenols extracted from Hibiscus sabdariffa L. inhibited lipopolysaccharideinduced inflammation by improving antioxidative conditions and regulating cyclooxygenase-2 expression. Bioscience, biotechnology, and biochemistry, 73(2), 385390. 
Lim, Y. Y., \& Murtijaya, J., 2007. Antioxidant properties of Phyllanthus amarus extracts as affected by different drying methods. LWTFood Science and Technology, 40(9), 16641669.

Nurkhasanah, Rahardhian M.R.R, 2015. Hepatoprotective Effect Of Hibiscus Sabdariffa L Extract On 7,12-dimethylbenz $(\alpha)$ antracene (DMBA) Induced Rat t. International Journal of Biological and Medical Research.

Reanmongkol, W. and Itharat, A., 2007. Antipyretic activity of the extracts of Hibiscus sabdariffa calyces L. in experimental animals.Songklanakarin J Sci Technol, 29(1), 29-38.

Sari, F., 2016. Toksisitas ekut ekstrak etanol kelopak rosella (Hibiscus sabdariffa L.) dan pengaruhnya terhadap fungsi hepar. Thesis. Program Pascasarjana Farmasi, Universitas Ahmad Dahlan Yogyakarta.

Sireeratawong, S., Itharat, A., Khonsung, P., Lertprasertsuke, N., \& Jaijoy, K., 2013. Toxicity studies of the water extract from the calyces of Hibiscus sabdariffa L. in rats. African Journal of Traditional, Complementary, and Alternative Medicines: AJTCAM/African Networks on Ethnomedicines, 10(4), 122-127.

Suboh, S.M., Bilto, Y.Y. and Aburjai, T.A., 2004. Protective effects of selected medicinal plants against protein degredation, lipid peroxidation and deformability loss of oxidatively stressed human erythrocytes. Phytotherapy Research, 18(4), 280-284. 